\title{
Late Holocene (2 ka) sea level, river discharge and climate interrelationship in the Taiwan region
}

\author{
Ping.-Mei Liew ${ }^{\mathrm{a}, *}$, Meng.-Long Hsieh ${ }^{\mathrm{b}}$ \\ ${ }^{a}$ Department of Geology, National Taiwan University, Taipei, Taiwan \\ ${ }^{\mathrm{b}}$ Department of Geological Sciences and Environmental Studies, Binghamton University, New York, USA
}

Received 6 March 1998; accepted 12 August 1998

\begin{abstract}
Based on the palynological study of two alpine lakes of the central mountains and a lake at 460 m elevation in northeastern Taiwan, a warm event which lasted several hundred years from about cal $2 \mathrm{ka}$, followed a cool-dry interval from about cal 3.7$2.0 \mathrm{ka}$. Evidence indicates a warmer annual temperature of $1-2^{\circ} \mathrm{C}$ and relatively higher precipitation during the warm interval compared with the cool-dry interval.

Sea level at cal $2-1.5 \mathrm{ka}$ is estimated to have been $130-150 \mathrm{~cm}$ higher than at present based on data from the Penghu Islands off western Taiwan (Chen and Liu, Quaternary Research 45, 254-262, 1996). In northern Taiwan, the corresponding sea level rise is recognized by a widening of the estuary in the Taipei Basin (Lin, Development of Taipei City, pp. 159-246, 1981), which is consistent with the distribution of archaeological sites around cal $2 \mathrm{ka}$.

The age of lower river terraces in northern (Lanyang) and southern (Erhjen) Taiwan, are consistently in the range cal. 2.5-1.5 ka. This suggests an island-wide morphological process, probably relating to climate change. This study discusses the inferred climate change and possible morphological responses. (C) 2000 Elsevier Science Ltd. All rights reserved.
\end{abstract}

\section{Introduction}

One of the aims of global change studies is to shed light on the result of changes to geological or morphological processes resulting from climatic change. The intensity of response in different areas may vary due to the geographical and/or geological setting. To understand the extent of the local impact of climate change on geological and morphological processes is important for enhancing sustainable development.

A warming event at about cal $2 \mathrm{ka}$ has been interpreted from the basis of pollen records obtained from three alpine lakes in northern, central and southern Taiwan (Figs. 1 and 2). These data were collected

\footnotetext{
* Corresponding author.

E-mail address: liewpm@sun01.gl.ntu.edu.tw (Ping.-M. Liew).
}

from Shuanglienpi $\left(24^{\circ} 45^{\prime} 57^{\prime \prime} \mathrm{N} ; 121^{\circ} 38^{\prime} 43^{\prime \prime} \mathrm{E}, 460 \mathrm{~m}\right.$ elevation). Chitsai $\left(23^{\circ} 45^{\prime} 10^{\prime \prime} \mathrm{N} ; 121^{\circ} 14^{\prime} 10^{\prime \prime} \mathrm{E}, 2890 \mathrm{~m}\right.$ elevation) and Chiamin Lakes $\left(23^{\circ} 17^{\prime} 42^{\prime \prime} \mathrm{N}\right.$; $121^{\circ} 01^{\prime} 34^{\prime \prime} \mathrm{E}, 3310 \mathrm{~m}$ elevation). The results of the effects of climatic change on vegetation of the latter two (Fig. 2; upper part) have been previously reported by Liew and Huang (1994) and Liew et al. (1995).

In an attempt to determine the amplitude of this warming event in northern Taiwan, this study augments previous palynological studies by examining pollen assemblages obtained from northern forests of different altitudes as an analog to those obtained from Shuanglienpi Lake in northern Taiwan. We then attempt to relate those vegetation changes, as well as climate change, to the development of marine and river terraces in the area by reviewing the available chronology. 


\section{Amplitude of the warming event shown in the pollen} diagram of Shuanglienpi Lake

Pollen assemblages from the core from Shuanglienpi Lake (lower part of Fig. 2) were used to estimate the amplitude of the Holocene warm event by comparison with surface pollen assemblages of present-day forests of different altitudes in northern Taiwan.

The Shuanglienpi core is $15 \mathrm{~m}$ in length, with its middle portion comprising (3-7 $\mathrm{m}$ in depth) coarse inorganic materials. The remainder of the core com- prises organic-rich mud. Pollen assemblages above and below the inorganic sediments are clearly different. The lower part $(7-15 \mathrm{~m})$ is characterized by elements of subtropical broad-leaved evergreen forests dominated by Castanopsis and Cyclobalanopsis, with Alnus, Quercus and Pinus also common. Spores are found only in very small amounts. In contrast to the lower part, where the assemblages in the upper part $(0-3 \mathrm{~m}$ in depth) are characterized by an increased number of spores and some subtropical lowland forest elements, such as Myrica, Lagerstroemia and Helicia. This rela-

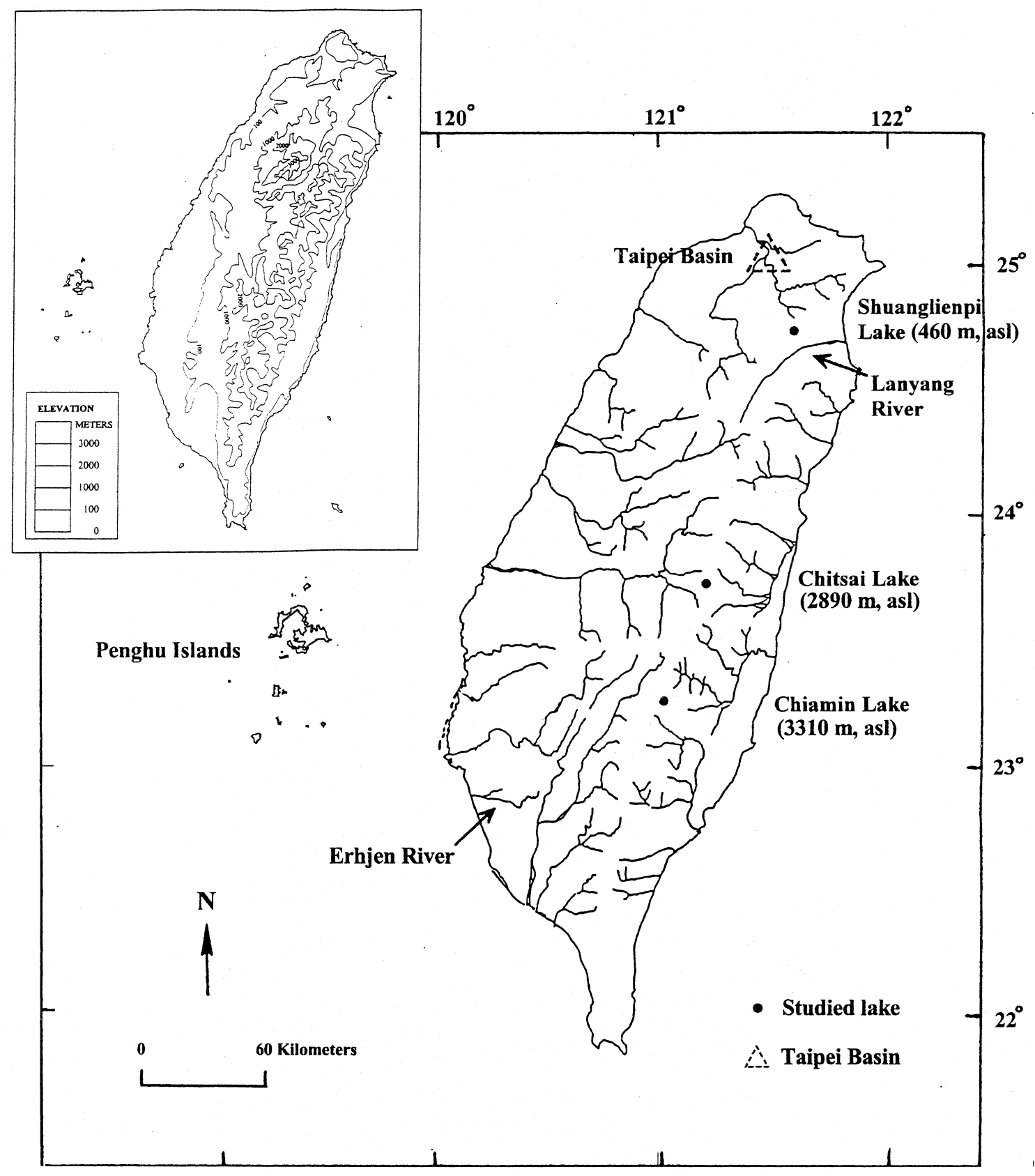

Fig. 1. Location of study sites in Taiwan, topographic data of the island shown in the upper map. 




(a) Simplified pollen diagram of Chiamin Lake sediments.

silt rock frogments

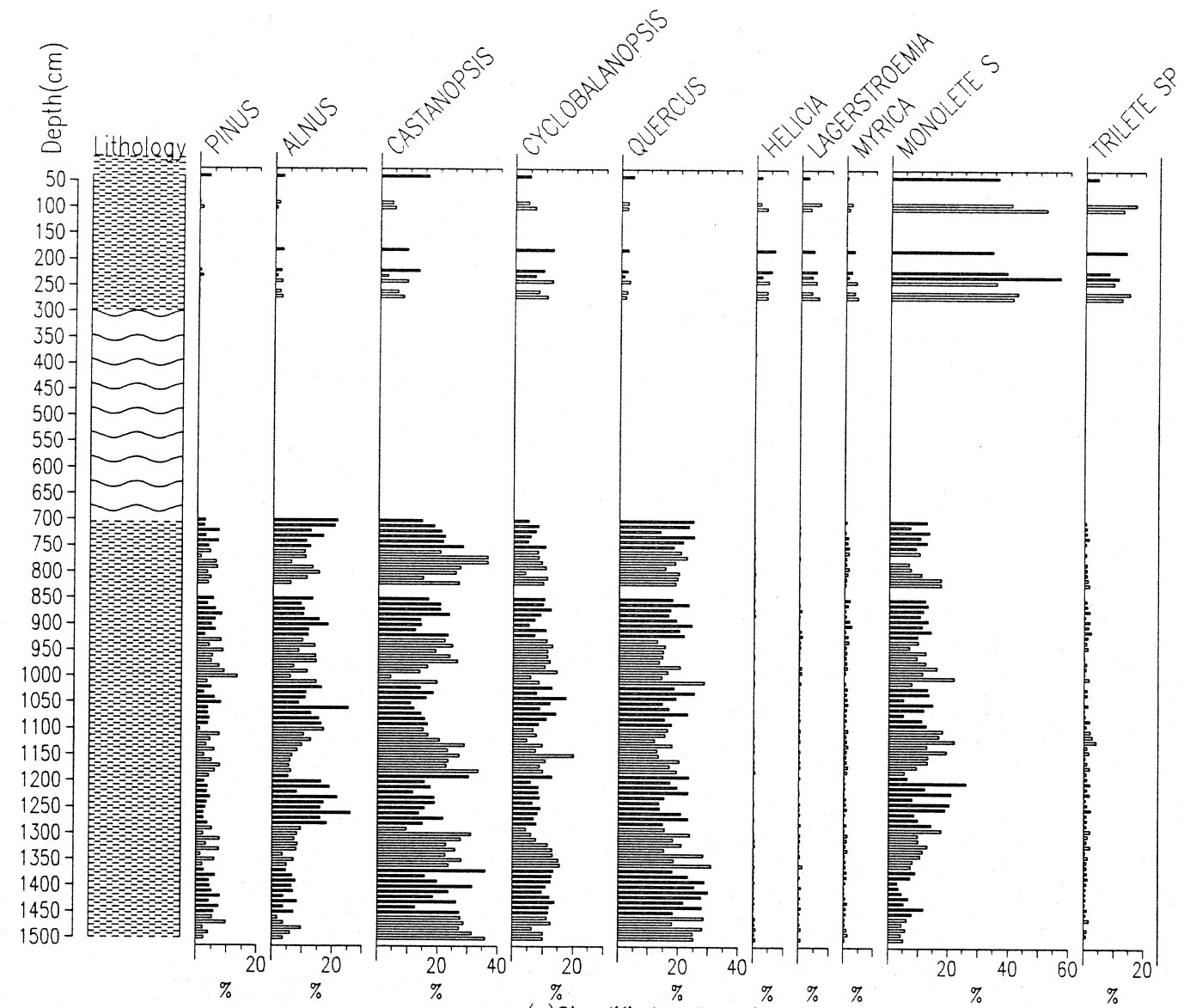

(c) Simplified pollen diagram of Shuanglienpi Lake sediments.



Fig. 2. Simplified pollen diagram of (a) Chiamin Lake and (b) Chitsai Lake (upper part) showing vegetational changes at about 2 ka BP and that of (c) Shuanglienpi Lake (lower part). 
tively higher number of spores in the upper part of the core is indicative of an increase in humidity because ferns in a pollen diagram of a subtropical area, especially when they are dominant, usually represent high humidity (Liew et al., 1998).

Using a sedimentation rate of $1.0 \mathrm{~mm} / \mathrm{yr}$ obtained from the higher elevation $(1673 \mathrm{~m})$ Yuanyang Lake $\left(24^{\circ} 34.8^{\prime} \mathrm{N}, 121^{\circ} 24.8^{\prime} \mathrm{E}\right)$ (Lin et al., 1995), the upper $3 \mathrm{~m}$ thickness of Shuanglienpi Lake was most likely deposited after 2-3 ka BP following a landslide event represented by the coarse inorganic sediments. The chronology of the fan terrace deposits of the Lanyang River (Fig. 1) in the vicinity of Shuanglienpi Lake similarly indicates that a landsliding event occurred around $2 \mathrm{ka} \mathrm{BP}$. This strongly suggests that the landslide material in the core was probably deposited 2-3 ka ago.

On close examination, a slight difference can be distinguished within the assemblages of the lower part of the core $(7-15 \mathrm{~m})$. Between 15-13 m, Alnus, Taxodiaceae are less common, whereas Castanopsis and Cyclobalanopsis are more so. Between 13-7 m depth, Alnus increases, but Castanopsis decreases. Fagus increases between 10.5-7.2 m, and
Abies is more abundant between 10.5-8.6 m. Thus, sediments below $7 \mathrm{~m}$ represents a relatively lower temperature interval, probably the cool interlude of cal 3.7-2 ka.

Fig. 3 shows the corresponding analysis of pollen assemblages of present day forests of different altitudes from 540 to $1480 \mathrm{~m}$ in northern Taiwan $\left(24^{\circ} 5^{\prime} \mathrm{N}\right.$; $121^{\circ} 2^{\prime} \mathrm{E}$ ) projected into the first and second principle variance axis (black dots). The assemblages of the upper two samples (EL90 cm and EL270 cm) and lower two (EL1000 cm and EL1460 cm) of the Shuanglienpi core (open dots) are projected on the map from the same analysis. Assemblages in the upper part are much closer to those of forests lower than $850 \mathrm{~m}$ in altitude; conversely, samples in the lower part are close to those forests at elevations of 1200-1400 m.

According to a plant ecological study of northern Taiwan (Hsu, 1991), the difference in annual temperature between these two forests of these two altitudes is $1-2^{\circ} \mathrm{C}$. Although the variation in precipitation is not available, the increase in the proportion of spores in the assemblages of the upper part of the core implies an increase in moisture. This suggests that the conditions in the upper part of the Shuanglienpi core are



Fig. 3. Correspondence analysis of the surface pollen data of northern Taiwan from 540 to $1480 \mathrm{~m}$ altitude (black dots) and the 4 samples of Shuanglienpi Lake (open dots, upper part $90 \mathrm{~cm}, 270 \mathrm{~cm}$; lower part $1000 \mathrm{~cm}$ and $1460 \mathrm{~cm}$ ) projected onto the map. The left column shows the altitude of the surface samples and the depth of the Shuanglienpi samples together with their scores. 
$1-2^{\circ} \mathrm{C}$ higher and are relatively moister than those in the lower part.

In their $\mathrm{Sr} / \mathrm{Ca}$ study of coral in southern Taiwan, Shen and Lee found a SST $1^{\circ} \mathrm{C}$ lower than today within the interlude of cal 3.7-2 ka BP (C.C. Shen and T. Lee, personal communication, 1996). However, temperature and precipitation change in this event was less than in the Holocene Optimum, as shown by the longer pollen record of Chitsai Lake (Liew and Huang, 1994) and the Toushe Basin (Kuo, 1994).

\section{Relatively higher sea level at about 2 ka BP}

To understand whether this interpreted warming even affected more widespread exogenetic processes in the region, the chronology of the marine terraces of the Penghu Islands, the paleogeography of the Taipei Basin, the sea level curve in South China, and the chronology of river terraces in Taiwan, were also considered.

\subsection{Penghu Islands}

Unlike the Island of Taiwan, the Penghu Islands are situated outside the front of the compressional zone of the Eurasian/Philippine plates. The Holocene marine terrace is characterised by only one level over most of this tectonically stable area. A recent study of this marine terrace shows that the highest Holocene sea level stand at cal $4700 \mathrm{BP}$ was $2.4 \mathrm{~m}$ higher than at present (Chen and Liu, 1996). Among the ten dates available from the Holocene marine terraces of the Islands, six are in between ${ }^{14} \mathrm{C}$ ages (uncalibrated) 4190 \pm 50 and $4720 \pm 40 \mathrm{yr}$ BP indicating a higher sea level during the middle Holocene. The other 4 samples from the outer edges of the terraces are between ${ }^{14} \mathrm{C}$ ages $2020 \pm 40$ and $1810 \pm 40 \mathrm{yr}$ BP and suggest a sea level stand 1.3-1.5 $\mathrm{m}$ higher than present during that time. If this high sea level stand between $2020 \pm 40$ and 1810 $\pm 40 \mathrm{yr}$ BP (cal $1680 \pm 40$ and $1410 \pm 40 \mathrm{yr}$ BP) is related to the warm event of $2 \mathrm{ka}$, then there was a small time lag in sea level response.

\subsection{Taipei Basin}

The Taipei Basin, in the northern part of Taiwan, is a triangular basin bounded by faults. In contrast to the surrounding hilly area, this basin has subsided since the middle Pleistocene. The area below $20 \mathrm{~m}$ elevation is about $240 \mathrm{~km}^{2}$. The lower $300 \mathrm{~m}$ of sediments in the Basin are mainly fluvial-lacustrine. Those sediments in the upper $60-70 \mathrm{~m}$, are of the Holocene age, within which a transgression is clearly registered (Liew et al., 1997), and indicate the maximum Holocene transgression occurred around $8 \mathrm{ka}$ BP. Terres- trial sediments aggraded faster than marine sediments after $6 \mathrm{ka}$. At about $5 \mathrm{ka}$, the Taipei Basin was a lacustrine environment.

Lin (1981) reconstructed the paleogeography of the Hsisintzuantzu shell mound stage based on the archaeological sites where ${ }^{14} \mathrm{C}$ ages (uncalibrated) of $2390 \pm$ $200,2010 \pm 200 \mathrm{BP}$ and $1940 \pm 200 \mathrm{yr}$ BP were obtained. He noted the enlargement of the Keelung River at that time. Archaeological evidence has shown that the Hsisintzuantzu shell mound is characterized by a remarkable greater number of species of marine to brackish water shells compared with earlier shell mounds, consistent with a sea level rise.

\subsection{South China}

Studies of sea level change in South China, including the Provinces of Fukien, Kwangtung and Hainan Tao $\left(19^{\circ} \mathrm{N}-26^{\circ} \mathrm{N} ; 110^{\circ} \mathrm{E}-120^{\circ} \mathrm{E}\right)$ (Huang et al., 1986) have shown that sea levels were relatively higher at about $5.8 \mathrm{ka}$ and $2.2 \mathrm{ka} \mathrm{BP}$ (uncalibrated ${ }^{14} \mathrm{C}$ ages). Those authors rechecked the 126 available dates and their occurrences within the dating material, evaluating the quality of former shoreline representation. They excluded the tectonic factor by compromising local uplift or subsidence and determined with a relatively consistent curve. The three peaks of sea level high were at about ${ }^{14} \mathrm{C}$ ages $5.8,2.2$ and $1.4 \mathrm{ka} \mathrm{BP}$. The shoreline was $4.5 \mathrm{~m}$ higher at about $5.8 \mathrm{ka}, 1.5 \mathrm{~m}$ higher at $2.2 \mathrm{ka}$ and $0.6 \mathrm{~m}$ higher at $1.4 \mathrm{ka}$ in the Pearl River Delta. The first two fluctuations were more widely recognized.

\section{Response in river discharge}

Wide, well-developed, river terraces exist in the Lanyang and Erhjen drainage basins (Fig. 1). The $66 \mathrm{~km}$ long Lanyang River drains straight through the northeastern slaty mountain ranges of the Taiwan Island, while the Erhjen River flows in a meandering course through southwestern mud and siltstone hills. Most terraces consist of thick sediments. The Lanyang terraces consist of coarse gravel of fan terrace deposits up to $120 \mathrm{~m}$ thick, and while fine-grained overbank river deposits reaching $15 \mathrm{~m}$ in thickness characterise terraces of the Erhjen River.

The chronology of the Lanyang Terraces (Fig. 4a) range from cal 2120-1540 yr BP (9 of the 13 dates fall into this interval), whereas the Erhjen terraces (Fig. 4b) range in age from cal 2410-1650 yr BP (all 8 dates are in this interval). In spite of the difference in the lithology and uplift rates of these two drainage basins, the ages of these terrace deposits are similar, showing a widespread aggradational episode ranging from cal 2500-1500 yr BP (Hsieh et al., 1997). The consistency 
in the timing of terrace deposition suggests an islandwide morphological processes that reversed the longterm incisional behavior. This environmental change is attributed to an increasing frequency of typhoons or precipitation which may have triggered frequent slope failures and increased sediment yield, resulting in river aggradation and/or lateral erosion.

\section{Discussion and conclusions}

The age of the warming event is around cal $1.8 \mathrm{ka}$ at Chitsai Lake in the middle of Taiwan and around cal $2.2 \mathrm{ka}$ at Chiamin Lake in southern Taiwan. The event lasted at least several hundred years. This may well indicate that there was a time lag of hundreds of years due to the latitudinal variations of this warm event. Alternatively, more intensive dating studies should be carried out in order to obtain more consistent age data. As previously stated, the chronology of the main lower terraces of the NE and SW drainage basins of Taiwan show very similar ages of around 2 ka. On the other hand, the ages at higher sea levels as indicated by marine terraces show local differences.

The ages of both the higher sea level of the Holocene Optimal and the $2 \mathrm{ka}$ event are younger in the Penghu Islands than in the provinces of southern China. Since these areas are close, it is suggested that further dating should be carried out to obtain better definition of the highest Holocene shorelines. Compared to the quick response of local river discharge, the response of regional sea level to climatic change may show some time lag. However, a very close relationship does exist between the $2 \mathrm{ka}$ warming event and sea level change in southern China if the range in dating is considered acceptable.

Off eastern Taiwan, the $\delta^{18} \mathrm{O}$ of marine core OR102-3 indicated that large amounts of fresh water influx occurred at about $2.4 \mathrm{ka}$ (Wang et al., 1994), which represents an unusual discharge event. This influx may have been due to the change in atmospheric circulation in the lower latitudes of the monsoon area. In north-central Thailand an increased runoff began at $1.7 \mathrm{ka}$ after a much drier interlude (Bishop and Godley, 1994). In the study of Holocene precipitation in



Fig. 4. Distribution of terraces (shaded area) of the studied area (a) the Lanyang River (northern Taiwan) and that of (b) the Erhjen River (southern Taiwan) with their available dates. The studied areas are indicated in the map of Taiwan. 
Rajasthan, India (Bryson and Swain, 1981; Swain et al., 1983), a desiccated condition possibly existed in the interval 3.5-1.5? ka. These studies indicate there has been a change to relatively wet-warm conditions since $2 \mathrm{ka}$ (or 2.5-1.5 ka) with temporal advances and lags at different latitudes in south Asia.

Responses of earth surface processes to climate change are always interesting for people to access. The ages of late Holocene river and marine deposits within a narrow time range indicate possible close relationships between climate and morphological processes. The dramatic effect of climate change on a subtropical, tectonic active island such as Taiwan is noteworthy.

\section{Acknowledgements}

The authors would like to thank colleagues working in sea level change studies in mainland China, Dr. Huang Zhenguo, Dr. Li Pingri and Mr. Chen Jungzen who provided many of the references. This enabled the authors to extend their local observations to a broader regional scale. The manuscript benefited from reviews by Drs Brad Pillans and Brent Alloway.

\section{References}

Bishop, P., Godley, D., 1994. Holocene paleochannels at Sisatchanalai, north-central Thailand: ages, significance and paleoenvironmental indications. Holocene 4 (1), 32-41.

Bryson, R.A., Swain, A.M., 1981. Holocene variation of monsoon rainfall in Rajasthan. Quaternary Research 16, 135-145.

Chen, Y., Liu, T., 1996. Sea level changes in the last several thousand years, Penghu Islands, Taiwan Strait. Quaternary Research 45, 254-262.

Hsieh, M.L., Chyi, S.J., Chen, B.L., Liew, P.M. 1997. Holocene river terraces in the Lanyang and Erhjen Rivers and their climatic implications. In: Program and expanded abstracts of Conf.
Geomorphology and Environmental Education across the Taiwan Strait, Taipei, pp. 65-70.

Hsu, Y.M., 1991. Structure and composition of the warm temperature rain forest of Lopei Mountain, North Taiwan. Master thesis, Botanical Department, National Taiwan Univ., 82 pp. (in Chinese).

Huang, Z., Li, P., Zhang, Z., Zong, Y., 1986. Changes in sea-level in the late Pleistocene in south sea coasts. In: International Geological Correlation Program Project No. 200 China Working Group, (Ed.), China Sea Level Changes. China Ocean Press, Beijing, pp. 178-194. (in Chinese).

Kuo, C.M., 1994. Pollen analysis of lake sediments in the Toshe Basin since older than $10 \mathrm{ka}$. Master thesis, Department of Geology, National Taiwan Univ., 82 pp. (in Chinese).

Liew, P.M., Huang, S.Y., 1994. A 5000-year pollen record from Chitsai Lake, central Taiwan. Terrestrial, Atmospheric and Oceanic Sciences 5 (3), 411-419.

Liew, P.M., Huang, C.Y., Tseng, M.H., 1997. Preliminary study on the late Quaternary climatic environment of the Taipei Basin and its possible relation to basin sediments. Journal of the Geological Society of China 40 (1), 17-30.

Liew, P.M., Kuo, C.M., Chen, A.C.T., Lou, J.Y. 1995. Climatic fluctuations during the last several millennia as indicated by lake sediments of Taiwan. In: Proc. IGBP-PAGES/PEP-II Symp. Nagoya, pp. 103-108.

Liew, P.M., Kuo, C.M., Huang, S.Y., Tseng, M.H., 1998. Vegetation change and terrestrial carbon storage of eastern Asia during the last glacial maximum as indicated by new pollen records of northern Taiwan. Global and Planetary Change 16 (17), 85-94.

Lin, C.C. 1981. Geology of Taipei. In: Wang, Kuo-Fan (Eds.), Development of Taipei City. Committee of Taipei Wan-Hsieng, Taipei, pp. 159-246 (in Chinese).

Lin, H.S., Lee, T.Q., Liew, P.M., 1995. Paleo-secular variation records from lacustrine sediments of Yuan-Yang Lake, northern Taiwan. Journal of the Geological Society of China 38 (4), 355370.

Swain, A.M., Kutzach, J.E., Hastenrath, S., 1983. Estimates of Holocene precipitation for Rajasthen, India based on pollen and lake level data. Quaternary Research 19, 1-17.

Wang, C.H., Shieh, Y.T., Chen, M.P., 1994. Holocene oxygen and carbon isotope records of core OR102-3 off southeastern Taiwan: Paleoceanographic implications. Terrestrial, Atmospheric and Oceanic Sciences 5 (3), 421-429. 